\title{
Rehabilitation of historic Shibam and Zabid, Yemen as an impulse for community and economy
}

Tom Leiermann ${ }^{1,2^{*}}$

\begin{abstract}
Conditions in Yemen involving armed conflict and all kinds of structural challenges have also their impact on the fate of its built heritage. Yemen's three World Heritage Sites have their particular significance, all of them representing a region with its own cultural background: Sanaa in the highlands, Zabid in the coastal Tihama, and Shibam in the remote desert valley of Hadramaut. Unlike the Old City of Sanaa, the two smaller sites struggle with the limited resources of low-developed hinterland. Both preserve a unique urban culture: Zabid with its many elements of elaborate artistry and a vernacular architecture highly adapted to tropical conditions, and Shibam as a dense structure of unique mud-built tower houses.

Preservation in a background of poverty, weak capacities of official structures, and even war destruction risks can only succeed in connection with active engagement and commitment of the community, which however is heterogeneous and heritage preservation is not always their priority. Efficient strategies must therefore link local livelihood interests to preservation concerns. Market quarter and housing rehabilitation in both cities in last years had wide backing, supported income and resulted in visible upgrading of the very heart of these cities-showing locals recovery of historic structures has its potentials - even in the extreme conditions of Yemen.
\end{abstract}

Keywords: Yemen, Earthen architecture, Heritage conservation, Zabid, Shibam, Vernacular architecture

\section{Living heritage in Yemen}

\subsection{Two cities in a conflict-torn country}

The architectural heritage of Yemen includes many historic cities and villages across the country but faces a range of challenges to which recent years of conflict have only added further risks. Two World Heritage Sites, Zabid and Shibam, together with a third site, the capital city of Sana'a, are famous as representatives of the specific vernacular architecture of their region.

Urban preservation and sensitive development in a conflict-torn country are seemingly a struggle with uncertain outcomes. In a situation where political authorities definitely have different priorities and communities are

\footnotetext{
*Correspondence: tom.leiermann@gmx.de

2 UNESCO Doha, Doha, Qatar

Full list of author information is available at the end of the article
}

confronted with poverty and manifold structural deficits, even in the times ahead, the conservation of heritage is not truly on the main agenda, and awareness as well as means and official backing are low.

An examination of the case of these two small cities shows the challenges of preserving a very vulnerable architecture but also the opportunities and the visible impact of preservation activities. This issue concerns not only aesthetic values and identity but also the role of civil society, social commitment, engagement and participation. Of course, conflicts and different interests are part of the story, so it is essentially also about flexibility, compromise and communication.

The two cities, one in the extreme east and the other in the extreme west of Yemen, are on different sides of the main front line and reflect quite different vernacular traditions and environments. Neither city suffered 


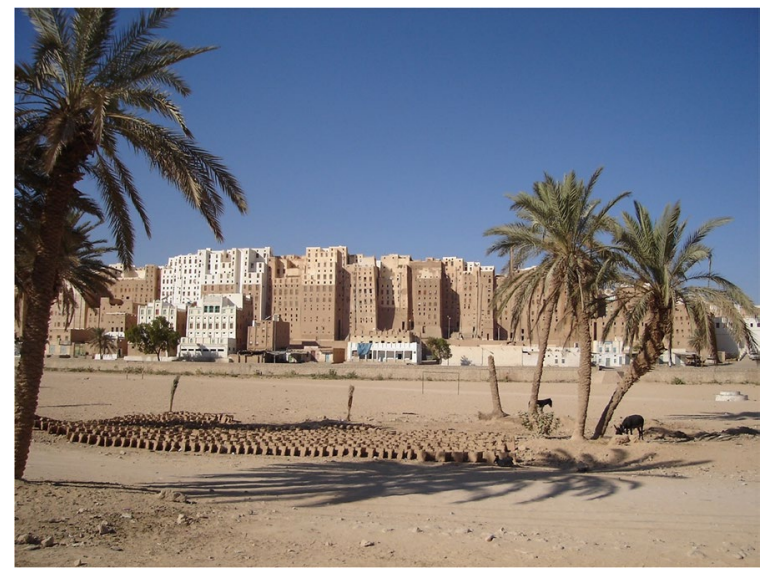

Fig. 1 Shibam, with mud-brick production in the dry riverbed (Source: the author)

direct destruction on a large scale, but they are country towns in the hinterlands with obviously limited economic potential. Their prominence as World Heritage Sites has led to only limited support but of course makes a difference: the two cases highlight the overall situation in Yemen, which to a great extent is home to a cultural landscape of unique character and value.

Zabid and Shibam were capital cities in the early Middle Ages but later became modest country towns. They contain beautiful monuments but are remarkable mainly for their overall urban pattern, which makes them ideal examples of living heritage: structures of houses and mosques used and lived in by people that have no value and no prospect of survival without these people. Vulnerability in these cases means that as long as the symbiosis between people and urban structures remains intact, a heritage site can survive, but there is no guarantee that it can be preserved in confrontation with the various current transformations and challenges in every aspect of life. A closer look at both cities shows what this means in a very concrete sense.

\subsection{Shibam}

Shibam is a dense fabric built completely of earthen tower houses of mostly six floors, a unique architecture that originated (according to all indications) in South Arabian civilisation (Fig. 1). Shibam forms a walled mount in the canyon-like Hadramout Valley that regularly forms an island in times of the seasonal floods that have enabled agriculture in the valley via complicated irrigation systems. This cultivation technology was among the achievements of ancient South Arabian civilisation, of which Hadramout was one of the main kingdoms and the only one for which the name and ethnic identity have survived to the present day. The walled city is almost certainly partly a natural mount and partly a tell, but archaeological excavations are not possible in this densely built, lived-in city. However, temple inscriptions found nearby prove that a city named Shibam did exist around 500BCE and played a regional role. Even though Shibam gained importance only after the destruction of the ancient capital and incense trade hub, Shabwa, which marked the end of the kingdom around 500 CE, its urban structure is clearly rooted in the ancient South Arabian civilisation preserved in the remoteness of the desert valley (Leiermann 2009).

What makes Shibam so iconic and unique is the typology of five- and six-floor tower houses, the only such tower houses built of earth brick worldwide. This unique architecture emerged from three roots:

- Mud brick is the appropriate building material in Wadi Hadramout, where the climate is extremely hot and arid and the desert stone is so hard that its use is traditionally limited to foundations.

- The typology of tower houses was the characteristic feature of the ancient South Arabian civilisation, in which the oriental atrium house was never adopted-the tower houses of Sanaa and the stelae of Axum are famous examples of this tradition. The antique invention of lime plaster fired in kilns made it possible to protect earth-built tower structures in heavy rains.

- The unusual setting of Shibam on a flood island and its continuous role as a trade centre resulted in extreme density and cohesion and secured the survival of the building type with higher authenticity than in other towns in the Wadi.

The first Western visitors to Shibam were the Bents in the 1890s-such was the remoteness of this valley, indicating its extraordinary conditions for the preservation of an ancient culture. There is probably no town in the world that still so closely resembles its appearance 2000 years ago as Shibam, the high one, as locals praise it in poetry (or the Manhattan of the desert, as Westerners call it). This unique continuity is even more astonishing given the high vulnerability of the building material. The earth-built houses of Shibam have a maximum life span of 300 years, including the wooden beams, doors, columns and windows made of local hardwood (jujube, or Ziziphus spinachristi), which are vulnerable to damage by termites. In addition, torrential flooding has been a constant danger, according to medieval sources (Lewcock 1987), and the last large flood in 2008 showed that disastrous flooding can wipe out earth-built houses within minutes.

Despite these vulnerability factors, Shibam, with its architecture, has survived over the centuries-not the 
substance of the houses, as after the destruction of an old earth-built house, nearly nothing remains; however, the urban community, the spatial organisation and the ways of local construction, housing and proportion have remained almost unchanged. As earthen architecture requires the constant renewal of each part-whitewashing each year, mud plaster every 10 years, and plastered parts every 30 years-even a wealthy Yemeni state and an overall rehabilitation programme could not guarantee further survival of these structures. Only the common sense and the commitment of the inhabitants, together with the skills of local master builders and their teams, can achieve the preservation of Shibam, but even this would not be enough in these times without additional support.

In the Hadramout Valley of the present day, Shibam is a relatively small country city of minor economic and administrative importance. As a major iconic tourist destination, Shibam encountered a constant tourist flow until the current conflicts arose, but the local people were never able to make a considerable profit from tourism. However, new challenges have added to the old vulnerability. The local community is proud of its history and prominence, but modern fashions and methods have found their way to Shibam. The rapidly growing population has created suburban sprawl, traffic and modern planning changes to the environment; palm yards are being given up, groundwater levels are falling dramatically, and local youths lack promising prospects. The specific flooding risk has prevented direct suburban sprawl around the walled city itself, but economic activities have shifted to new zones with better car access, and the old suq quarter is drying up. The authorities are weak, and preservation restrictions are often not observed. Shibam is still built completely of mud brick, but cement is used widely, creating salty humidity and ugly infractions. Garbage, plastic and air conditioners are among the phenomena that compromise the traditional urban integrity. Wealthier citizens have built fancy dream villas rather than renovating their inherited "town palaces". These are only some of the actual problems to which the impact of the current crisis has been added.

\subsection{Zabid}

Zabid, on the other side of Yemen, is situated in the Tihama coastal plain near the Red Sea in a rather tropical climate, resulting in completely different housing traditions and settlement structures (Fig. 2). This town covers a wider area dotted with small, low houses around courtyard compounds adapted to tropical conditions. In contrast to the oriental atrium house, the Zabidi household consists of a complex system of open courtyards (qabal and fina), traditionally organised along extended family

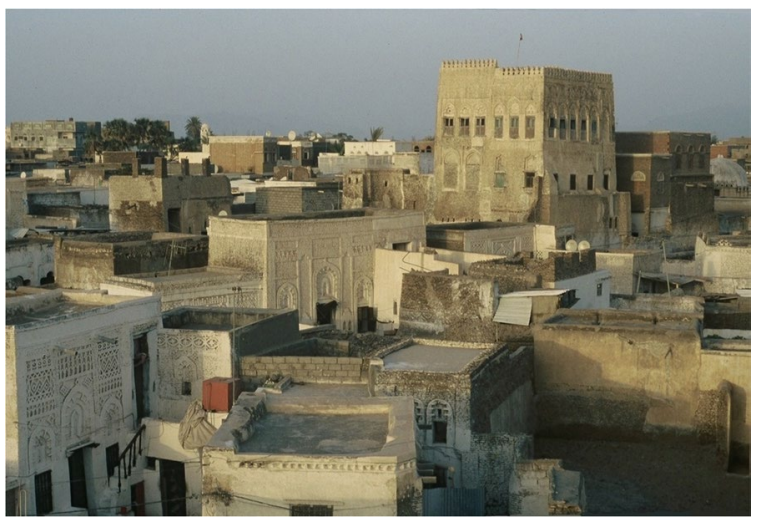

Fig. 2 Zabid, urban pattern with decorated historic façade (Source: the author)

bonds, with one-room houses serving different purposes and providing cells for individual families. Life in the courtyards and small houses is adapted to the need for ventilation. The traditional building material is burned brick and plaster, but there is always a high percentage of organic materials, such as brushwood and mud, especially for families of lesser wealth; today, the use of cement blocks and industrial bricks is predominant.

This architecture is known for abundant inside and outside decoration (Bonnenfant 2008). The extraordinary richness of forms and colours reflects different aspects of Zabid's particular history. On the one hand, it is part of the remarkably rich folk art typical of the Tihama coast along the Red Sea, which is often labelled "Yemeni Africa" and indeed is a cultural sphere reflecting various influences from around the Red Sea. On the other hand, Zabid was Yemen's capital in the Sulayhid period and, even more significantly, in the Rasulid period, when Yemen gained a level of wealth and artistic relevance that it never reached again. Zabid was not only the capital (shared with Taiz in the highlands) but also a centre of scholarship, with one of the most renowned universities in the Islamic world, and of arts and craftsmanship. Many patterns and ornaments in Zabidi houses can be linked to this period and make this vernacular architecture even more interesting and valuable.

Today, Zabid is a small market city with approximately 20,000 inhabitants at the centre of a wide but remote and impoverished country hinterland. The tourism potential was low even in peace conditions, as the surrounding plain has no touristic reputation, the numerous important historical structures are mostly not open to the public, and the city lacks iconic significance. Of more concern from the point of view of preservationists is the inflationary spread of informal modern buildings, which already dominate the appearance of the city and led to its 
inscription as World Heritage in Danger long before the current conflicts started. ${ }^{1}$

Under this impression and with the realistic prospect that instability and low awareness of preservation concerns make any tendency toward improvement very unlikely, some international experts believe that Zabid is already a lost case as a heritage site. However, many observations contradict this belief. Even in many places dotted with bold, higher new buildings, the majority of the historical substance (i.e., the vernacular buildings built before 1980) is still existing and not in immediate danger. The 86 historic mosques, the four gates, the citadel and most parts of the suq district are also preserved. The integrity of the traditional fabric is substantially damaged, but a high degree of transformation is the normal situation in a city of small-scale buildings, of which a high percentage were made from organic material and highly adapted to family constellations that changed with marriages, births and deaths. Freezing the actual structures would be neither historically accurate nor possible. On the other hand, uncontrolled development would lead to the disappearance of most traditional features and the complete transformation of the old city to an impoverished mélange of ruins partial relics and informal modernisation.

Again, the only chance for the survival of the historical architecture is an approach that integrates all local demands and expectations with solutions that make use of the potential of the traditional architecture wherever possible. This approach requires financial support from international donors and consultancy support from local authorities, builders and inhabitants; obviously, local forces are not able to develop appropriate solutions alone. However, the approximately 3,600 traditional houses can hardly be turned into a museum - this architecture can survive only if local interests and actions are in accordance with preservation efforts.

We must remember that maintaining premodern life conditions as they existed only 40 years ago (and to some extent still do exist) is not an option in Zabid, as anywhere else. However, while the historic cities of Europe, such as Paris, Prague and Palermo, underwent numerous modernisations in recent centuries that equipped houses with large windows, comfortable bathrooms and central heating, such updates have yet to be made in most households in Zabid. Rough and cheap modernisation in

\footnotetext{
${ }^{1}$ Zabid was inscribed as a World Heritage Site in 1993 and inscribed on the List of World Heritage in Danger in 2000. The assessment by the World Heritage Centre of UNESCO states, "The visual and physical integrity of the property is so threatened by these new developments and encroachments that up to $40 \%$ of the structures are vulnerable. There is an urgent need to halt this decline and reverse the undesirable changes" (World Heritage List of UNESCO, Zabid Page. https://whc.unesco.org/en/list/611).
}

an emerging country does not always lead to the sensitive solutions that, incidentally, emerged even in developed countries only after many dramatic losses. Blaming locals and hoping to achieve improvement by passing strict laws will not help much; instead, initiative and commitment by locals can be accompanied by financial and technical support. Good results of good practice speak for themselves and will succeed if they are in accordance with local expectations and are developed by or in close cooperation with engaged inhabitants or groups.

In the special case of Zabid, there is an additional challenge that may not sound as strange to those familiar with the conditions of the Middle East as to outsiders. An unfortunate incident led to violence, and respect for preservation concerns reached an absolute low point in 2012. Police forces tried to stop a group of men building an informal family house on public ground, and the dispute following rejection of the police demands ended in a gunshot fatality. As a result, the already weak local authority for preservation was completely rejected by the community. Any attempt at preservation in this situation was doomed to failure. At this point, rehabilitation of the market quarter proved to be a good opportunity to regain the favour of the local people.

\section{Rehabilitation}

\subsection{The market quarters}

One example of successful rehabilitation in recent years is the market quarters-an integral and central part of the historical fabric of both cities. These quarters consist of narrow lanes flanked by stalls that may be of minor architectural interest themselves. What makes them valuable in terms of preservation is their atmospheric intensity and their essential function for social life and economics and thus for the quality of life of the old town as a whole. Improving conditions can increase the attraction and income possibilities and show partners and visitors the potential of the sensitive modernisation of a historic city.

In Shibam, the suq quarter is as small and narrow as the whole site. All shops are ground-floor premises of the historic mud-brick tower houses, a building type that requires thick walls and narrow openings in the ground floors. Consequently, the shops are very narrow and of limited attraction for modern use, e.g., as a supermarket. They also contradict the belief that shops need direct car access in a country where only a few can afford cars, but pedestrian zones are unknown. The social quality of a historic suq is appreciated, but models of integrative modernisation are needed.

In Zabid, the market quarter covers the central zone of the four quarters of the historic city. The suq includes several covered market lanes around six market mosques, one of which is the Ashâ'ir mosque, reputedly the oldest 
mosque in the city. Shade roofs once covered most of the lanes, but only small parts of the old roofs have survived. Poor tin or palm-leaf sheds cover most lane sections to give shade but create the impression of a shantytown, limiting acceptance and potential. Here, too, the concurrence of market life along the highway is growing. Unclear property constellations and ruins have added to the poor appearance of the market quarter and limited investment and commercial success.

The decline of the old market quarters is an indication of a general loss of historic substance and cultural identity, while successful rehabilitation of the suq would support local identity and engagement. The local suq provides opportunities not only for traders and craftsmen but also for unskilled labourers and attracts all kinds of customers, i.e., enables activities for most or even all inhabitants and is therefore the place where the benefits and potential (or failures) of the historic city are most apparent.

Since a Yemeni-German cooperation project started activities in Zabid, ${ }^{2}$ the revitalisation of the market quarter has been one of the objectives described in several studies. ${ }^{3}$ Some implemented measures included the rebuilding of some ruined stalls, but the project closed when the crisis began. Since 2016, a rehabilitation programme financed by the German Foreign Office and initiated by the author started with the rehabilitation of shade roofs at the main crossing in the very heart of the city, i.e., the east-west and north-south lanes next to the Ashâ'ir Mosque. ${ }^{4}$ The implementation was coordinated with the local branch of the Historical Cities Authority, GOPHCY, and the affected shopkeepers.

The building design followed that of the existing historic sections in Zabid. The roof exceeds the height of the shop stalls, similar to a basilica scheme. Brick columns support the roof and create space for a row of openings above the shops that give light to the lanes. The roof consists of round beams, layers of brushwood and broken bricks covered by mortar and lime plaster. The work included the restoration of some walls, foundations and facades. The upgrading of the quarter resulted in the

\footnotetext{
${ }^{2}$ Project for the Development of Historic Cities in Yemen (PDHCY) 2016, a German-Yemeni cooperation project by GTZ/GIZ, Eschborn/Germany and Social Fund of Development (SFD), Sanaa/Yemen, 2009-2012, called Medina.

${ }^{3}$ Burkhard von Rabenau, Cleveland/Ohio, economic consultant of SUDP/ PDHCY; various internal project studies, 2002-2010.

${ }^{4}$ Rehabilitation measures by Cultural Support Fund of Auswärtiges Amt (State Dept., Germany):

-Rekonstruktion Suq-Überdachung in Zabid (Reconstruction of suq roofing in Zabid) 2016/2017;

- -Restaurierungsmaßnahmen Altstadt Zabid (Rehabilitations, Old City of Zabid) 2019/2020.
}

opening of more than a dozen new shops and services, mainly by young entrepreneurs.

Shibam has been a major town in the Hadramout Valley over centuries but lost importance to Seyun and other cities in the region during the 12th century. As a result, most former shops within the old suq closed. This development has endangered both the remaining business and the value of the old city as a place of social meeting and leisure. It also affects the willingness of locals to invest in the old town.

As a first step toward market rehabilitation, the shops were equipped with new shadow sheds. The work also included the renovation of some shop interiors and repair of historical wooden doors. The area was paved as part of a technical infrastructure project implemented immediately before the conflict began. Together, these upgrades led to the opening of several new shops and an improvement of the whole market quarter that should make it more competitive. A characteristic feature of Shibam is the tea shops, some of which are open air; these also obtained new shade roofs and new locally made iron chairs. Such details may seem minor, yet given the fact that open space is still largely undefined in the area and public equipment has been largely reduced to broken plastic chairs and rough tin roofs, some new accents for public spaces can indeed be inspiring for local improvements.

\subsection{Housing programmes}

Apart from walls and gates, government buildings and mosques with their daily social and religious functions, the historic cities consist mainly of private houses. In Shibam, the historical earthen tower houses need constant maintenance in order to protect them against erosion and rainwater and otherwise preserve stability (Leiermann 2017). As a tenant in old Shibam, I was warned to travel for some days to the coast in a season of cloudy weather: "It may rain, and somebody has to be home in case of a leak", I was told. An earthen structure not in use and unmaintained can very quickly become a ruin.

Another concern is the termites. Wooden structures are essential for earthen tower houses. They provide the structural flexibility that prevents major susceptibility to earthquakes in an active seismic zone not far from the Rift Valley and the Gulf of Aden; indeed, historical sources mention frequent destruction by flood events (Lewcock 1987), but earthquakes seem not to be a large risk for the tower houses (I stayed on the fifth floor of a Shibam tower house during a medium-level earthquake, after which no structural damage was observed within the city). A higher risk for the wooden elements is termites; ceilings and wooden columns seem to have a high resistance in inhabited spaces, but windows and doors 
are vulnerable. Buildings of no permanent use, such as garden houses in the oasis or storage facilities, are even more at risk. In these cases, mud-brick vaults were the logical choice, but the practice of these constructions has been abandoned in recent decades. With the help of old master builders, it has been possible to revive this technology; in modern buildings, however, steel beams are the standard solution for ceilings in earthen buildings.

The main structural problem in Shibam, however, is the modern sewage and drinking water infrastructure. The introduction of drinking water and sewage pipes to the city, in which water access and drainage were organised by wells and water pipes for centuries, created a permanent risk for humidity in the ground and caused leaning walls, cracks and the eventual destruction of buildings. Amusingly, this unique city of earth-built tower houses is probably the only city in the world with zero plants intra muros (some planting pots on my roof terrace were the only exception). While old Shibam is surrounded by palm yards, no plants are allowed inside, as plants require underground irrigation and would create a risk for foundations. Consequently, in-ground pipes violate the logic of this town. An ambitious infrastructure project around 2010 had to develop very specific pipe-in-pipe solutions and other installations to combine modern demands with the specific requirements of the historic architecture. ${ }^{5}$

Social constellations are an essential element in the preservation management of a historic city such as Shibam. Some wealthy families possess several large houses, some of which are full of interesting interior and exterior architectural details. However, some of these families live in Persian Gulf countries and leave their houses empty; thus, their interest in preservation is generally low. Poorer families would be willing to preserve their houses as they are but do not have the means to maintain earthen architecture as required. Here, rehabilitation programmes can support incentives, but it is vital to manage such support in a fair and transparent way to strengthen and not weaken the community with its complicated structures, rivalries and emotions.

The most essential component of preservation management in Shibam is the traditional building system of master builders and their teams. They are the ones who transfer the knowledge of traditional construction from generation to generation (Fig. 3). They are the strongest asset in the preservation of Yemeni cities, as most of the necessary techniques are still known and practised. Of

\footnotetext{
${ }^{5}$ The Shibam Infrastructure Project (2008-2015) was initiated by PDHCY and funded by SFD, Sanaa (Yemen): It covered the renewal of sewage, water supply, electricity and telephone networks, including the pavement of the old city of Shibam. When the works were halted as a result of the conflicts, almost all components were terminated.
}

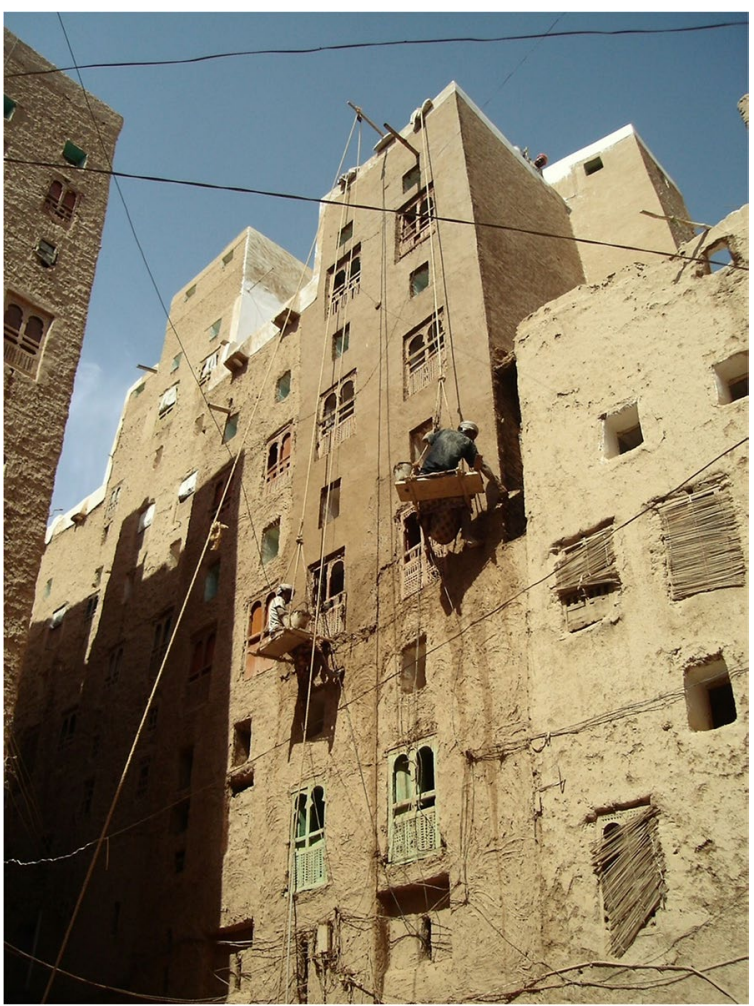

Fig. 3 Shibam, renovation of an earthen tower house (Source: the author)

course, modern transformations have entered this master builder system: on the one hand, the master builders rely on their customers and do not refuse modern fashions if requested. In theory, the master builders' association and the governmental office for preservation should enforce preservation requirements for building practices, but these mechanisms are still very weak. On the other hand, official buildings and new planning practices confront master builders with architects and new methods to which they sometimes have difficulty adapting. Indeed, some new challenges need new approaches, but essentially, the architects should adapt to the master builders, not the other way around-they are the base of any solid dealing with the traditional architecture, and any weakening of their functioning system would be disastrous.

One important factor is the extent to which modern life expectations can align with or contradict the traditional space organisation that accompanies the historical substance. Historic houses in Shibam, with their lack of furniture and glassless windows, still adapt to the way people live there, and both the narrow structures and the mud material support fulfil demands in the hot and arid conditions.

In Zabid, in contrast, the traditional organisation of living mainly in open courtyards shifted to some extent 
to living in closed apartment buildings with air conditioners. Obviously, building activities that allow more density are widespread and endanger the coherence of the city to an increasing degree (Leiermann 2011). This means that the preservation of the old town must follow two main strategies: rehabilitating the historic houses and developing solutions for appropriate building within the open compounds because the building of housing units in open space or degraded areas will continue in the coming years. Attempts to formulate guidelines for building activities have thus far had little impact on practices but need to be intensified if Zabid is to have a future as a coherent historic city. The rebuilding of a kiln in Zabid to fire traditional bricks within the actual UNESCO programme is an important step in this direction, and new actualised (and simplified) guidelines are being developed.

The rehabilitation of traditional and historic houses also requires different responses. The traditional type of house (murabba) is a complex system of elements that is too complicated to present in full here. The basic oneroom type is oriented east-west with openings to the north and south, which protects against direct sunlight. The symmetric entrance façade includes a door with stairs, windows and fanlights and a number of classical brick and plaster ornaments. Inside the entrance façade, the main long wall opposite the entrance ( $\mathrm{s} a d r$, or breast) and the short walls (khadd) have not only distinct names but also different compositions of decoration, niches, shells, cupboards and other elements (Fig. 4). Displayed decorative household items and colourful ceiling paintings are part of the traditional interiors.

This house type occurs from the small, simple, earthbuilt hut to the elaborate merchant house with large dimensions, rich ornamentation and several room extension types, such as the riwâq (anteroom), mabraz (reception room), saffa (loggia) and first-floor premises (khalwa), all connected to courtyards. The larger mansions form complex building groups (sometimes with bridges across public lanes, known as maslaq). Houses differ not only in size and level but also in actual conditions, ranging from well-maintained and well-kept houses to ruins in all states of intactness or degradation.

Recent housing programme activities ${ }^{6}$ concentrated as a first phase on the renewal of roofs. Zabid's traditional roof is constructed of organic materials and reflects Zabid's roots in the vernacular traditions of the Tihama coast and even close links to maritime trade. Brushwood is laid in grids and rhombs or diagonals and fixed

\footnotetext{
${ }^{6}$ Cash for Work Project: Promoting Livelihood Opportunities of Urban Youth in Yemen, 2018-2021; initiated by UNESCO Gulf countries and Yemen, Doha/Qatar, and funded by the EU.
}

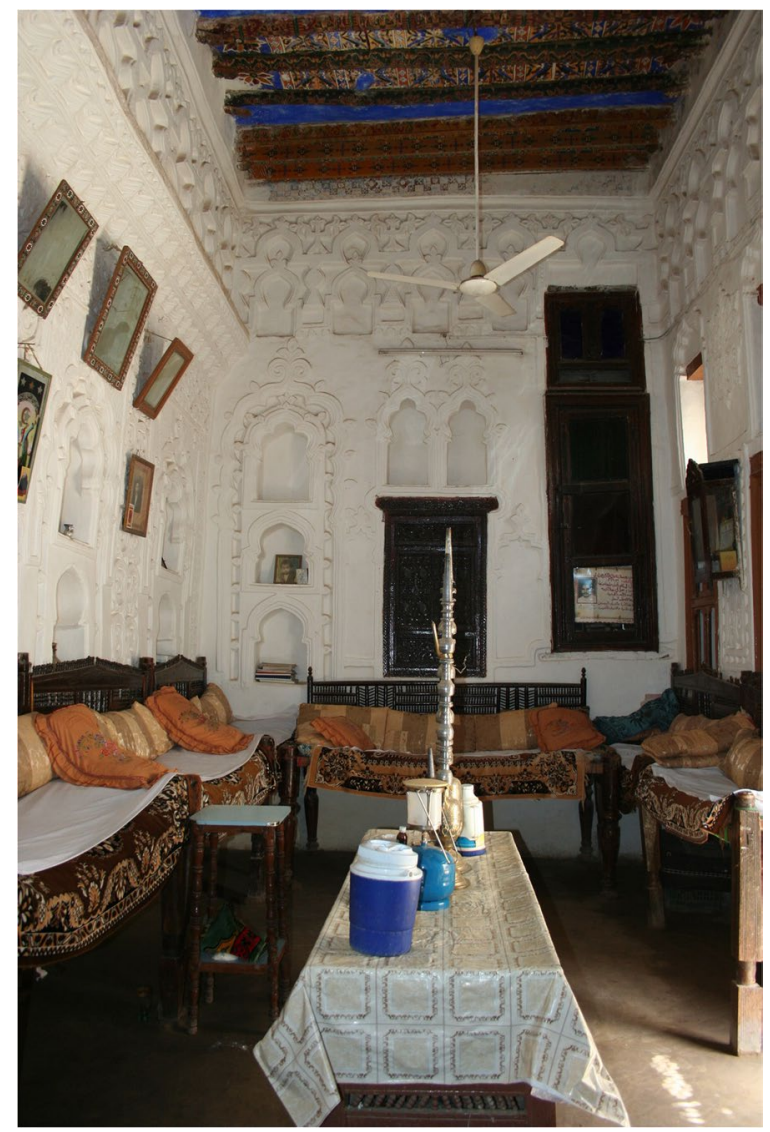

Fig. 4 Zabid, interior of a historic merchant house (Source: the author)

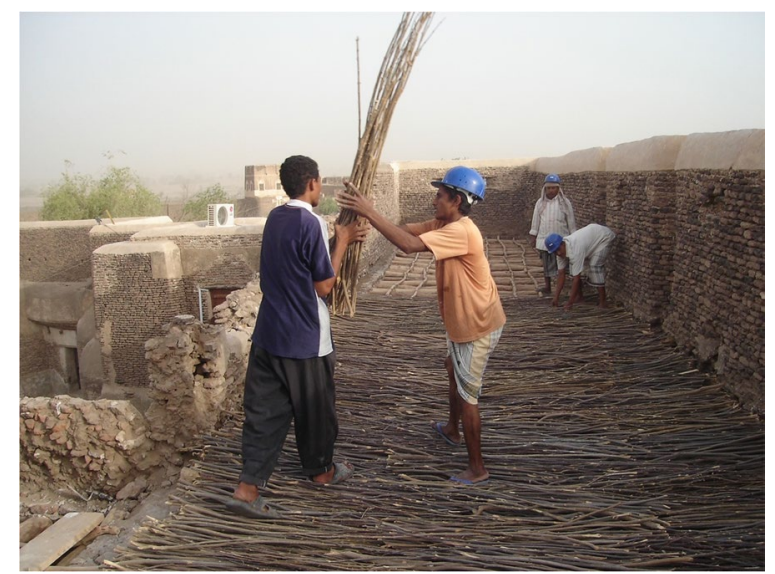

Fig. 5 Zabid, traditional roofing with brushwood (Source: the author)

by string knots (the various layers were described earlier) (Fig. 5). This construction needs regular renewal and is not very costly. However, again, the traditional system of housing and renovation crafts is not entirely intact: new cheap construction materials have appeared on the 
market, social discrepancies or property constellations have undermined maintenance, social expectations have changed, and so on. The result is a high number of rotten ceilings, eventually leading to leakage and holes. Once a house is abandoned, its fate as a ruin is almost certain. All elements of value are removed, and the elements can accelerate the erosion process.

This includes even mansions of outstanding value, the houses of the famous merchant dynasties of Zabid. Not all these families were able to keep their wealth, and maintaining these monumental houses is often beyond their capacity. Living in these houses as they are is already a commitment that helps to avoid major degradation and keeps respect for traditional values alive. In some of these houses, the roofs are in critical condition, and torrential rains have had an impact in recent yearsclimate change has had an effect and will continue to do so. The vast majority of less wealthy inhabitants welcome repair or renewal of their roofs.

Of course, this strategy is not sustainable because external support is not a solution forever; in the long run, locals must organise maintenance themselves, and local authorities must monitor and manage the process and intervene where necessary. However, it is still a long process to build the necessary awareness, professionalism and engagement-and in the meantime, many of the structures and much knowledge could unfortunately vanish without support from external subsidies.

With these risks in mind, it may be an option to give up on these organic roofs and introduce steel beams or the like-most elements of the traditional architecture could harmonise with such an innovation. Although traditional roofs are still practised and widely accepted, such questions have increasing relevance in regard to new buildings.

\subsection{The role of crafts}

A strong component of the historic architecture in Shibam and Zabid is the many wooden details. The ceiling and roof beams in Shibam and their structural role have already been mentioned. An interesting feature in Shibam is the wooden columns enabling large living spaces-a technology that was obviously already known in ancient South Arabia but survived only in Hadramout, while in the highlands and in the Tihama coastal area, the length of available wood defines the width of traditional rooms, which rarely exceeds three metres. In Hadramout, however, people refer to their main rooms as two-, three-, four- or even six-column rooms (the latter are restricted to wealthy merchant houses).

The columns are part of the strict modular system of the earthen architecture in Hadramout. Any house is an overall three-dimensional grid of constructive lines

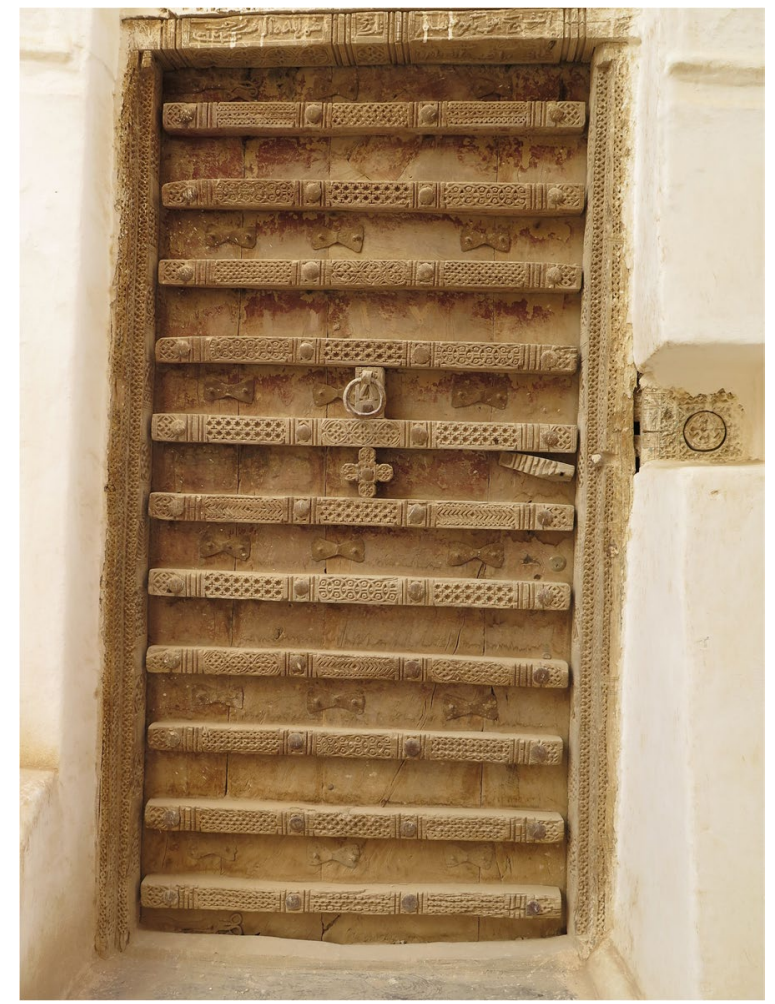

Fig. 6 Shibam, wooden entrance door detail (Source: the author)

that can be covered by either walls or columns, while the space between the constructive cross-points can be used for open space, windows, doors or, if openings are not welcome, wall niches. These niches can serve as lighting, open shells or closed cupboards. This modular system is one reason for the "Manhattan" appeal that struck early Western visitors when they first came to Shibam.

All these columns are carved with ornaments, both the posts and the capital detail called qabsh (ram), which incidentally is a frequent element in ancient oriental architecture. Other elements of carved woodwork are carved shutters-most of which have already been replaced by recent work in soft imported wood or even wood imitations. The same is true for internal doorsthe traditional doors with their famous wooden locks (an old technology that functions with no metal parts) are left mainly for storerooms on ground floors and first floors (where the need for thicker walls prevents wooden columns and makes use for living space impossible). Most of the historical entrance doors are still in place; they are made of hardwood with large iron nails of special strength, and the variety of their ornamental carvings is a story of its own (Fig. 6). However, even here, iron replacements are much cheaper than carved 
woodwork, and without repairs, their number will diminish constantly.

Another case is traditional wooden grid windows, the early medieval window type before the introduction of glass windows. They survived in Shibam and the surrounding area because ventilation was welcome, but the wide use of air conditioners favours a shift to glass windows in metal frames-a major threat to facades and traditional buildings. In old Shibam, the old wooden windows are still accepted, and their restoration in recent years has probably helped to ensure the survival of this rare archaic element-the characteristic double-arch windows are a typical feature of early medieval architecture in large parts of the orient, and in Djenné and Timbouctou, they are called "Yemeni windows".

In all developments such as these, there is a constant loss of historical substance, and it is possible to slow it rather than to stop it. However, what I used to call the "day-X-effect" can be an issue. In a city with so many renovation and rebuilding activities, such as earthenbuilt Shibam and small-scale Zabid, it is essential to develop renovation and building methods that are adapted to, if not identical to, traditional methods and proportions-generally, local master builders are able and willing to engage in such practices, but support by professional preservation experts is needed to decide what is adaptive. The Charter of Venice is not a great help in developing criteria here, for a strict definition of authenticity does not work when dealing with organic materials and constructions with a short lifespan.

In Shibam, this effect took place some years ago. When German-Yemeni cooperation started in 2002, many windows had been replaced by grids of imported soft wood in a kind of colonial-neoclassical style without the classical double arch and without the variety of ornaments that was typical for the older windows. In traditional practice, even the window shapes were varied within one room, mostly according to an A-B-A scheme, with each façade containing multiple window shapes. The variation in forms was a basic principle of traditional artistry, while modern practice makes this almost impossible. If somebody orders 12 windows in a "traditional design", the carpenter will execute identical windows according to the sample hanging on the workshop wall. Convincing carpenters to invest additional care, try to be creative or even create exact replicas of old windows that had to be replaced as too rotten to be repaired was not easy, but eventually the picture changed. An increasing number of windows had to be replaced, and today, the appearance of Shibam's facades is much closer to the traditional appearance than it has been for decades. The revival of the traditional shapes has convinced carpenters and inhabitants-and today, Shibam's carpenters even produce traditional grid windows for other villages and cities; thus, a conservation initiative has proven economically sustainable.

In Zabid, once again, the situation is more complex. The stunning interiors of the merchant houses with their abundant plaster ornamentation, carved woodwork on shutters, doors and tables, and colourful ceilings are testimonies to craftsmanship that could occupy restoration teams for decades. Renovation of plasterwork is relatively easy (even the exact renewal of original shapes according to detailed drawings is a challenge for the master builders); on the other hand, the reconstruction of the elaborate painted ceilings that, like all woodwork, will eventually need replacement is very ambitious. It has thus far never been tried and will need more training and capacities. In the case of the painted ceiling of the small but fine Ali Ibn Ahmed Mosque, reconstruction was planned, but when international support stopped due to the increasing crisis, the few remnants were stored somewhere, and the ceiling was replaced by traditional brushwood without any painted wood panels. Local craftspeople were certainly not able to perform such reconstruction work unaided, and they cannot be blamed for the failure. Such losses will continue, as hundreds of valuable old houses and 86 mosques still contain many more architectural elements of value than preservation efforts will be able to conserve. Some of these mosques, such as the Grand Friday Mosque, Iskanderiya Mosque in the citadel and Asha'ir Mosque in the market quarter, contain fresco paintings and elaborate stucco works that date back to the Rasulid time (ca. 14th century), important links to the vernacular artistry of private houses. These works alone are more than the current preservation capacities can cover.

Carpentry is another issue for preservation in Zabid. The traditional carving style in Zabid combines the inherited motives of the Rasulid and Ottoman era and influences by Indian carpenters of the large Indian minority in the 19th century. The woodwork of Zabid fills many antiquity shops in Sanaa, museums in the Gulf region and-certainly, although hidden from the public-numerous private households in wealthier countries. Many examples are still in place, but more are missing. The traditional way of housing - - having a large number of trays, plates and vases in addition to the plaster décor-is in rapid decline in comparison to the documentation provided by Paul Bonnenfant around 2000 (Bonnenfant 2004).

The other side of the coin is engagement workshops and restoration activities by both male and female teams that provide hope for further commitment. Some new buildings have integrated carved doors or window 
shutters in what is meant to be the traditional stylethese efforts are not always convincing, but they reflect emerging awareness. The renaissance of traditional crafts has thus far not reached the level it did in Shibam, but Zabid offers much more to be done-there is a potential that needs to be further developed and supported. One observation in 2013 may illustrate the situation: when I entered the old mosque-madrasa al-Ghusseiniya, one of the sites of the historic university, I saw some fine calligraphic inscriptions that were covered by thick layers of oil colour some years ago. When I asked the young worshippers, they told me they had uncovered the inscriptions by their own initiative. I brought the restorer from an official restoration programme (another programme that unfortunately was interrupted when the conflict began) to the place, and he asked the youngsters how they had done it: "with a screwdriver". He explained that they had destroyed the original blue background colour (of which some remnants are still visible), but they said they did not know better. How could they? These young people live in a society with other priorities, and they are largely uneducated about these historical issues. However, they still have the desire to participate in beauty and culture. This is a base for more, if it is given a chance.

\subsection{Approaches and strategies}

Rehabilitation in conditions such as those in Yemen cannot and should not follow classical blueprints. Professional capacity and financial resources alone are not necessarily guarantees of sustainable success. Since 2002, I have worked in the historic cities in Yemen, mainly in Shibam but also in Sanaa, Zabid and Aden, for different organisations, both international and national, and as an independent consultant. Not everything I was involved in was a success, but several activities were. Some historic buildings were rescued, and many more were secured for their next future, but more promising than the immediate impact of project activities was always the point when active members or groups of the communities or the local authorities would take over the initiative and continue or even initiate activities that combine modernisation and preservation. The last goal of external expertise is always to make itself no longer needed.

Traditional methods of building never needed architects and external experts or external funding. In ideal circumstances, this system would function again because local conditions have not changed in every respect, and traditional construction methods are normally efficient and ecologically sustainable. Building with mud bricks is highly adapted to local conditions; it provides good climatic conditions and saves energy, and the materials can be $100 \%$ recycled. It is work intensive, which makes it expensive for house owners but creates good income possibilities for less educated local youth. An interesting detail is the traditional toilets in the tower houses, connected with dry shafts for the dry waste, which is separated from the liquid. The remains are collected and distributed to farmers who pay for collection. The system is perfectly adapted and efficient but is no longer socially accepted, so an increasing number of people have switched to modern water toilets. They consume more water and create increased sewage, which attracts more insects and requires more costs and health risks by chemical treatment; however, without public acceptance, the traditional methods can no longer be used.

Another typical case in Shibam is the increased use of cement to protect vulnerable parts of earthen buildings despite the physical risks of long-term damage. Some of these interventions are a serious risk for historic structures, but there is serious aesthetic damage as well. The neoclassical "Greek style" motifs in gypsum or cement are very popular in the region and cover villas and new buildings but are increasingly also entering the old towns and villages. Each renovation of earthen facades requires the whole removal of the surfaces to a depth of two fingers. This is used for aesthetic "upscaling" that can easily lead to the rapid destruction of historical façade features.

The necessary response to these developments has been some pilot cases in which remaining historic plaster plinths with historic curved shapes were carefully documented and master builders requested to restore plinths according to the documented detail drawings ${ }^{7}-$ a technique that was not known in traditional building and was not needed, as aesthetic principles did not change much over the centuries. Within a short time, we achieved some nicely restored plinth zones and could see the "dayX-effect": illegal transformations in the neoclassical fashion became rare, while local builders and house owners started to renovate their plinth zones according to traditional techniques and proportions.

This is a good example of the effect of model cases that are normally much more convincing than awareness programmes, brochures and assemblies. Due to the priorities of internal donors, local associations (NGOs or CBOs) can play a constructive role, but that always depends on personalities and constellations. Any single group hardly represents the whole community, and particular interest by some can always provoke counterreactions. However, generally, such associations are a good instrument to reflect public opinions and to find partners in addition

\footnotetext{
7 Pilot case implementation 2004-2009 within SUDP/PDHCY Yemen (GIZ/ SFD), see above; documented, e.g., in: A + U No. 447, Tokyo/Japan 2007 in Aga Khan Award for Architecture, 2007, p 116, featuring the award for Rehabilitation of the City of Shibam, Yemen by GTZ (Germany) and GOPHCY (Yemen).
} 
to official authorities, which often do not represent the whole reservoir of knowledge and commitment in a local community. However, in the long run, the authorities are always the institutions that must manage the sites, and their capacity strengthening should always be at the centre of cooperation programmes-in close contact with the master builders.

Not only awareness but also ownership is essential. In the GIZ Shibam project that won the 2008 Aga Khan Award (Johnston 2007, 34-49), there was a basic principle of supporting house renovations only on the condition of the owner's own contribution. This was certainly a good strategy in Shibam, where the community and its commitment provided a solid base for this strategy, while the community and the challenges in Zabid were much more complex. Here, publicly funded "light tower projects" were probably necessary to prepare the ground on which programs with a higher ownership component can hopefully be built in the near future. Again, there is no binding blueprint, and appropriate strategies must always be based on the conditions of the particular community and in close cooperation with it.

\section{Conclusions}

After more than four years of armed conflict, the future of Yemeni heritage, like the future of Yemeni society in general, is more insecure than ever. To a certain degree, however, the situation has stabilised. At the level of municipal and community life, there is some normality and communal engagement. On the international side, UNESCO started with a wider initiative in the main heritage sites, including Shibam and Zabid, in addition to the historic centres of the two capital cities, Sanaa and Aden; the author is engaged in this programme as an architectural expert and consultant.

The crucial question for the future of these historic cities is whether the close cooperation of conservationists, authorities and communities can deal with the general challenge of neglect and lack of preservation concern that is a fact throughout most Middle Eastern countries. Poverty, rough modernisations and weak respect for conservation regulations remain challenges, but successful rehabilitation of structures and ensembles can serve as strong signals if locals regard them as positive. They will do so if economic needs and expectations are in line with conservation activities and if social benefits are also visible. In such a case, a historic site such as Shibam or Zabid can serve as a push for local development. Nevertheless, it is too early to say whether sustainable development in these two cases can succeed.

Generally, the preservation of historic architecture has a chance only if social and economic demands do not contradict it. This is especially true of vernacular architecture in low-income countries such as Yemen. Strong preservation laws, public or international finance and tourism exploitation can be helpful, but normally, vernacular heritage cannot survive on its own.

Therefore, only close cooperation with locals using local knowledge and needs, combined with professional ideas with some background of international standards and methods, can lead to appropriate and sustainable solutions. Market quarter rehabilitation and housing programs in Zabid and Shibam show that such initiatives can motivate locals and may inspire further initiatives for sustainable local development in favour of preserving their rich and unique vernacular heritage.

\section{Acknowledgements}

Not applicable.

Author's contributions

The author read and approved the final manuscript.

Funding

Not applicable.

Availability of data and materials

Not applicable.

Declaration

Competing interests

The author declare that they have no competing interests.

Author details

${ }^{1}$ ICOMOS Germany, Berlin, Germany. ${ }^{2}$ UNESCO Doha, Doha, Qatar.

Received: 26 June 2021 Accepted: 16 November 2021

Published online: 09 December 2021

\section{References}

Bonnenfant, Paul. 2004. Zabid au Yemen, Archéologie du vivant. Aix-enProvence: Edisud.

Bonnenfant, Paul. 2008. Les Maisons de Zabid, Eclat et douceur de la decoration. Paris: Maisonneuve \& Larose.

Johnston, Pamela. 2007. Intervention architecture: Building for change. London: I.B.Tauris.

Leiermann, Tom. 2009. Shibam, Leben in Lehmtürmen: Weltkulturerbe im Jemen. Wiesbaden: Reichert Verlag.

Leiermann, Tom. 2011. "Das Compoundhaus in Zabid." In Jemen-Report, 40-53. Freiburg: Deutsch-Jemenitische Gesellschaft.

Leiermann, Tom. 2017. Preserving Shibam: The City of towering mud houses. In Architectural heritage of Yemen: Buildings that fill my eye, ed. H.J. Trevor . London: Gingko Library.Marchand

Lewcock, Ronald B. 1987. Wadi Hadramawt and the Walled City of Shibam. Paris: UNESCO.

\section{Publisher's Note}

Springer Nature remains neutral with regard to jurisdictional claims in published maps and institutional affiliations. 